\title{
Pengaruh Partisipasi Anggaran Terhadap Kinerja Manajerial Dengan Gaya Kepemimpinan Sebagai Variabel Moderating Pada Bank BNI di Pekanbaru
}

\author{
FAIZAH KAMILAH $^{1}$, ZULIA KHAIRANI ${ }^{2}$, AZNURIYANDI $^{3}$ \\ 1,2,3 Dosen Tetap Fakultas Ekonomi Universitas Lancang Kuning \\ Jln. Yos Sudarso KM 8 Rumbai \\ E-mail : faizahkamilah76@yahoo.com
}

\begin{abstract}
The present research was conducted by a survey method at the Bank BNI of Pekanbaru. It sought to examine the effect of budgetary participation on managerial performance with leadership style as moderating variables Bank BNI of Pekanbaru. The population included 12 Bank BNI in Pekanbaru. The data were collected by distributing questionnaires to 84 respondents, but only 80 of them were used. The data were analyzed by a multiple regression. The results show that participation in the budgetary preparation had an effect on the managerial performance with significance level 0.002 (alpha 0.05). Leadership style could moderate the effect of participation in the budgetary preparation on the managerial performance with significance level 0.044 (alpha 0.05).
\end{abstract}

Keywords: participation in budgetary preparation, leadership style, managerial performance

Upaya meningkatkan mutu pelayanan terbaik dan untuk memperbaiki standar pelayanan, manajemen di dunia perbankan perlu memperhatikan kinerja pencapaian unit-unit pelaksana pelayanan tersebut. Salah satu upaya mengalokasikan sumber daya bank dalam pengendalian kinerja pelayanan bank adalah sistem anggaran (Bastian, 2005). Kebanyakan Bank yang merupakan keuangan publik masih mengandalkan sistem anggaran tradisional dalam perencanaan anggarannya. Sistem anggaran tradisional ini memiliki wujud seperti berorientasi pada input, tidak terkait dengan perencanaan jangka panjang dan bersifat tahunan (Bastian, 2005). Sistem anggaran bank berorientasi pada kinerja (performance budgeting) merupakan upaya terobosan prinsip anggaran tradisional yang kerap dilakukan. Walaupun ada kesulitan dalam menentukan output measurement, sistem anggaran ini dapat diandalkan dalam reformasi keuangan bank karena memiliki banyak kelebihan dalam akuntabilitas keuangan bank.

Kinerja manajerial merupakan salah satu faktor yang dapat meningkatkan keefektifan organisasional. Dengan melakukan pengukuran kinerja maka dapat memastikan apakah pengambilan keputusan dilakukan secara tepat dan objektif. Dengan kinerja bawahan yang bagus dan kebersamaan antar kelompok dapat mengurangi rasa tertekan akibat adanya anggaran (Bastian 2005). Kinerja manajerial dipengaruhi oleh beberapa faktor seperti partisipasi penyusunan anggaran dan gaya kepemimpinan.

Dalam hal ini jika penyusunan anggaran hanya berdasarkan kehendak atasan tanpa melibatkan partisipasi bawahan maka dapat menimbulkan kesulitan bagi bawahan untuk mencapainya. Sebaliknya jika penyusunan anggaran hanya disusun sesuai kehendak bawahan maka juga dapat menimbulkan rendahnya motivasi bawahan dalam mencapai targettarget yang optimal.

Supriyono (2005) menyatakan bahwa untuk mengatasi ketidakkonsistenan hasil-hasil riset, diperlukan pendekatan kontinjensi (Contingency). Pendekatan ini memberikan suatu gagasan bahwa hubungan antara partisipasi penganggaran dan kinerja manajerial diduga dipengaruhi oleh faktor atau variabel yang bersifat 
kondisional. Salah satu variabel kondisional tersebut adalah variabel moderating.

Variabel gaya kepemimpinan adalah variabel yang dapat memoderasi hubungan antara partisipasi penyusunan anggaran dengan kinerja manajerial. Gaya kepemimpinan merupakan norma perilaku yang digunakan oleh seseorang pada saat orang tersebut mencoba mempengaruhi perilaku dengan orang lain seperti yang ia lihat (Thoha, 2008). Efektivitas partisipasi penganggaran sangat dipengaruhi oleh gaya kepemimpinan manajemen (Sumarno, 2005). Untuk itulah dalam penelitian ini menggunakan variabel moderasi gaya kepemimpinan.

Gaya kepemimpinan mempengaruhi lingkungan perencanaan organisasi, teori $\mathrm{X}$ Mc Gregor dalam Lubis (2010) menjelaskan gaya kepemimpinan yang otoriter dan dikendalikan secara ketat dimana kebutuhan akan efisiensi dan pengendalian akan efisiensi dan pengendalian mengharuskan pendekatan manajerial tersebut untuk berurusan dengan bawahannya.

Kinerja manajerial merupakan salah satu faktor yang dapat meningkatkan keefektifan organisasional. Sumadiyah dan Susanta (2004) melihat kinerja manajer berdasar pada kemampuan manajer dalam melaksanakan tugas manajerialnya. Kinerja manajerial meliputi kemampuan manajer dalam: perencanaan, investigasi, pengkoordinasian, evaluasi, pengawasan, pemilihan staff, negoisasi, perwakilan dan kinerja secara menyeluruh telah ditetapkan.

Menurut Rudianto (2009), anggaran mempunyai fungsi utama yaitu :

a. Alat Perencanaan

b. Fungsi koordinasi

c. Fungsi komunikasi

d. Fungsi motivasi

e. Fungsi pengendalian dan evaluasi

f. Fungsi pendidikan

$$
\text { Menurut Supriyono }
$$

penganggaran partisipatif adalah suatu proses penyusunan anggaran yang melibatkan setiap manajer pusat pertanggung jawaban dan mereka memiliki kesempatan untuk menjelaskan dan memberikan alasan atas anggaran yang diusulkan. Partisipasi penganggaran didefinisikan sebagai suatu proses dimana kinerja individu akan dievaluasi, diberikan penghargaan, atau hukuman berdasarkan dari tingkat pencapaian target anggarannya (Chong dan Johnson, 2007).

Menurut Thoha (2008) Gaya kepemimpinan merupakan norma perilaku yang digunakan oleh seseorang pada saat orang tersebut mencoba mempengaruhi perilaku dengan orang lain. Dalam hal ini usaha menyelaraskan persepsi di antara orang yang akan mempengaruhi perilakunya akan dipengaruhi menjadi amat penting kedudukannya. Gaya kepemimpinan mewakili keterampilan dan sikap pemimpin dalam organisasi. Gaya perilaku seorang pemimpin untuk mengatur dan merumuskan peranan-peranan dari anggota-anggota kelompok atau para pengikut mengenai kegiatan yang harus dikerjakan oleh masing-masing anggota kapan dilakukan dimana dilakukan dan bagaimana tugas-tugas itu harus dicapai.

Adapun penelitian terdahulu dapat dijelaskan sebagai berikut: Soemarno (2005) meneliti pengaruh komitmen organisasi dan gaya kepemimpinan terhadap hubungan antara partisipasi anggaran dan kinerja manajerial. Hasil penelitian ini menyatakan bahwa terdapat pengaruh dan hubungan negatif yang signifikan antara kinerja manajerial dan partisipasi anggaran, terdapat pengaruh positif signifikan komitmen organisasi terhadap hubungan kinerja manajerial dan partisipasi anggaran, dan pengaruh gaya kepemimpinan terhadap hubungan antara partisipasi anggaran dan kinerja manajerial adalah tidak signifikan.

Nor (2007) melakukan penelitian tentang desentralisasi dan gaya kepemimpinan sebagai variabel moderating dalam hubungan antara partisipasi penyusunan anggaran dan kinerja manajerial. Hasil penleitian ini yaitu pertama, terdapat pengaruh positif signifikan antara kinerja manajerial dengan partisipasi penyusunan anggaran. Kedua,

p.ISSN: $2407-800 \mathrm{X}$ e.ISSN: 2541-4356 
144 Pengaruh Partisipasi Anggaran Terhadap Kinerja Manajerial Dengan Gaya Kepemimpinan Sebagai Variabel Moderating Pada Bank BNI di Pekanbaru (Faizah Kamilah, Zulia Khairani, Aznuriyandi)

kesesuaian antara partisipasi penyusunan anggaran dan kinerja manajerial dengan faktor kontijen (desentralisasi dan gaya kepemimpinan) terhadap kinerja manajerial tidak signifikan.

Mediaty (2010) melakukan penelitian tentang pengaruh partisipasi penyusunan anggaran, dan gaya kepemimpinan terhadap kinerja aparatur pemerintah daerah provinsi sulawesi selatan. Hasil penelitiannya yaitu Partisipasi penyusunan anggaran, dan gaya kepemimpinan teruji secara bersama-sama (simultan) berpengaruh positif dan signifikan terhadap kinerja aparatur pemda Provinsi Sulawesi Selatan.

\section{METODE}

Jenis data yang digunakan mengacu pada data kualitatif. Sedangkan sumber data adalah data primer. Lokasi dalam penelitian ini adalah Bank BNI di Kota Pekanbaru. Populasi dalam penelitian ini adalah seluruh manajer dan kepala bagian yang terlibat dalam proses penyusunan anggaran Bank BNI di Kota Pekanbaru. Sedangkan responden dalam penelitian ini yaitu manajer tingkat menengah dan manajer tingkat bawah dari Bank yang ada di Pekanbaru. Jumlah Bank BNI yang ada yaitu 12 Bank BNI di Kota Pekanbaru. Pengumpulan data yaitu metode survei kuesioner. Teknik pengambilan sampel pada penelitian ini adalah Purposive Sampling. Pengujian kualitas data menggunakan uji validitas data dan uji reliabilitas data. Model regresi akan menghasilkan estimator tidak bias yang baik jika memenuhi asumsi klasik yaitu bebas autokorelasi, multikolinearitas dan heteroskedatisitas.

Menurut Ghozali (2005) Untuk menguji regresi dengan variabel moderating digunakan uji interaksi. Uji ini sering disebut dengan Moderated Regression Analysis (MRA). Kedua hipotesis yang dikemukakan diuji dengan dengan persamaan regresi sebagai berikut :

Persamaan Regresi Pertama

Diuji dengan persamaan regresi :

$$
\mathrm{Y}=\alpha+\beta_{1} \mathrm{X}_{1}+\varepsilon
$$

Persamaan Regresi Kedua

Diuji dengan persamaan regresi :

$\mathrm{Y}=\alpha+\beta_{1} \mathrm{X}_{1}+\beta_{2} \mathrm{X}_{2}+\beta_{3}\left(\mathrm{X}_{1} \mathrm{X}_{2}\right)+\varepsilon$

\section{HASIL}

Gambaran mengenai masing-masing variabel dalam penelitian ini dilihat dari jawaban responden untuk variabel kinerja manajerial, partisipasi anggaran dan gaya kepemimpinanmenunjukkan secara keseluruhan jawaban rata-rata responden terhadap tiap item pertanyaan telah diterapkan dengan baik. Hasil uji validitas dan reliabilitas untuk variabel kinerja manajerial, partisipasi anggaran dan gaya kepemimpinan yang didapat tiap variabel valid dan reliabel.

Berdasarkan penjelasan diatas dapat disimpulkan bahwa dari masing-masing variabel dalam penelitian ini telah terbebas dari multikolinearitas. Hal ini dapat dilihat dari nilai VIF yang kurang dari 10 dan nilai toleransi lebih besar dari 0,1 . Untuk hasil uji autokorelasi tidak terdapat autokorelasi baik positif maupun negatif sehingga Ho diterima dan layak digunakan dalam penelitian. Untuk hasil uji heteroskedastisitas yaitu bahwa scatter plot memiliki titik-titik yang menyebar dan tidak membentuk pola tertentu. Maka dapat disimpulkan bahwa tidak terjadi adanya heteroskedastistas. Untuk hasil uji normalitas data yaitu bahwa data tersebar disekitar garis diagonal. Oleh karena itu dapat disimpulkan bahwa persyaratan normalitas data dapat terpenuhi.

Persamaan regresi yang diperoleh dari hasil pengujian hipotesis pertama adalah : $\mathrm{Y}=55,024+0,871 \mathrm{X}_{1}$. Persamaan regresi dari hasil pengujian hipotesis kedua adalah $: \mathrm{Y}=3,019+0,002 \mathrm{X}_{1}+0,249 \mathrm{X}_{2}+$ $0,038 X_{1} X_{2}$. Nilai koefisien determinasi hipotesis pertama sebesar 0.699. Angka ini menjelaskan bahwa 69\% kinerja manajerial dipengaruhi partisipasi anggaran sedangkan sisanya $31 \%$ kinerja manajerial dijelaskan oleh variabel lainnya, seperti wewenang, kecukupan anggaran, dan lain-lain. Nilai koefisien determinasi hipotesis kedua sebesar 0.643. Angka ini menjelaskan 
bahwa $64 \%$ kinerja manajerial dipengaruhi partisipasi anggaran dan gaya kepemimpinan sedangkan sisanya $36 \%$ kinerja manajerial dijelaskan oleh variabel lainnya, seperti seperti budaya organisasi, komitmen tujuan anggaran, desentralisasi, locus of control dan lain-lain.

\section{PEMBAHASAN}

Pengujian pada $\mathrm{H} 1$ dilakukan untuk menguji pengaruh partisipasi anggaran terhadap kinerja manajerial. Dari hasil pengujian terlihat $\mathrm{Ha}$ diterima dan $\mathrm{Ho}$ ditolak. Oleh karena itu dapat disimpulkan bahwa partisipasi anggaran berpengaruh signifikan terhadap kinerja manajerial. Temuan ini konsisten dengan hasil penelitian sebelumnya yang dilakukan oleh Coryanata (2007), Soemarno (2005), Supriyono (2004), Suardana dan Suryanawa (2008), Yusfaningrum dan Ghozali (2005). Penelitian ini tidak sejalan dengan penelitian yang dilakukan oleh Poerwati (2001) dan Subur (2004) yang menunjukkan hasil bahwa partisipasi penyusunan anggaran tidak mempunyai pengaruh terhadap kinerja manajerial.

Pengujian pada $\mathrm{H} 2$ dilakukan untuk menguji pengaruh partisipasi anggaran terhadap kinerja manajerial dengan dimoderasi oleh variabel gaya kepemimpinan. Dari hasil pengujian terlihat Ha diterima dan Ho ditolak. Oleh karena itu dapat disimpulkan bahwa partisipasi anggaran yang dimoderasi oleh gaya kepemimpinan berpengaruh signifikan terhadap kinerja manajerial. Hasil penelitian ini sejalan dengan penelitian Soemarno (2005), Mediaty (2010). Dan bertentangan dengan penelitian yang dilakukan oleh Nor (2007).

\section{SIMPULAN}

Berdasarkan hasil pengujian dan analisa yang telah dibahas pada bab sebelumnya, maka peneliti memuat beberapa kesimpulan sebagai berikut :

1. Berdasarkan hasil uji dari hipotesis pertama dapat dilihat bahwa partisipasi penyusunan anggaran berpengaruh signifikan terhadap kinerja manajerial, dengan melihat signifikansi sebesar $0,002(0,002<0,05)$.

2. Berdasarkan hasil uji hipotesis kedua dapat dilihat bahwa gaya kepemimpinan berpengaruh terhadap hubungan antara partisipasi penyusunan anggaran dengan kinerja manajerial. Hal ini dibuktikan dengan nilai signifikansi sebesar 0,044 $(0,044<0,5)$.

3. Berdasarkan hasil koefisien determinasi untuk hipotesis pertama diperoleh nilai koefisien determinasi sebesar 0.699 . Angka ini menjelaskan bahwa 69\% kinerja manajerial dipengaruhi partisipasi anggaran sedangkan sisanya $31 \%$ kinerja manajerial dijelaskan oleh variabel lainnya, seperti wewenang, kecukupan anggaran, budaya organisasi, komitmen tujuan anggaran, desentralisasi, locus of control dan lainlain.

4. Berdasarkan hasil koefisien determinasi untuk hipotesis kedua diperoleh nilai koefisien determinasi sebesar 0.643. Angka ini menjelaskan bahwa 64\% kinerja manajerial dipengaruhi partisipasi anggaran dan gaya kepemimpinan sedangkan sisanya $36 \%$ kinerja manajerial dijelaskan oleh variabel lainnya, seperti seperti wewenang, kecukupan anggaran, budaya organisasi, komitmen tujuan anggaran, desentralisasi, locus of control dan lainlain.

\section{DAFTAR RUJUKAN}

Andrianto, Yogi. 2008. Analisis Pengaruh Partisipasi Penyusunan Anggaran Terhadap Kinerja Manajerial Dengan Kepuasan Kerja, Job Relevant Information dan Kepuasan Kerja Sebagai Variabel Moderating (Studi Empiris Pada Rumah Sakit Swasta di Wilayah Kota Semarang).

Bambang Sardjito dan Osmad Muthaher. 2007. Pengaruh Partisipasi Penyusunan Anggaran Terhadap

$$
\text { p.ISSN: } 2407-800 X \quad \text { e.ISSN: } 2541-4356
$$


146 Pengaruh Partisipasi Anggaran Terhadap Kinerja Manajerial Dengan Gaya Kepemimpinan Sebagai Variabel Moderating Pada Bank BNI di Pekanbaru (Faizah Kamilah, Zulia Khairani, Aznuriyandi)

Kinerja Aparat Pemerintah Daerah : Budaya Organisasi Dan Komitmen Organisasi Sebagai Variabel Moderating. Simposium Nasional Akuntansi X. Makasar.

Brownell, P. and McInnes, M. 1986. "Budgetary Participation, motivation, and manajerial performance". The Accounting Review, Vol. 61, No. 4.

Corynata, Isma. 2007. Pelimpahan Wewenang dan Komitmen Organisasi Dalam Hubungan Antara Partisipasi Penyusunan Anggaran dan Kinerja Manajerial. Simposium Nasional Akuntansi (SNA) VII Denpasar.

Daft, Richard L. 2010. Era Baru Manajemen. Buku 2. Edisi 9. Salemba Empat. Jakarta.

Ghozali, Imam. 2005. Aplikasi Analisis Multivariat dengan Program SPSS. Universitas Diponegoro. Semarang.

Ghozali, Imam dan Yusfaningrum, Kusnasriyanti. 2005. Analisis Pengaruh Partisipasi Anggaran terhadap Kinerja Manajerial melalui Komitmen Tujuan Anggaran dan Job Relevant Information (JRI) sebagai Variabel Intervening (Penelitian terhadap Perusahaan Manufaktur di Indonesia), Simposium Nasional Akuntansi VIII, Solo.

Hansen Dan Mowen. 2001. Akuntansi Manajemen. Salemba Empat. Jakarta.

Ikhsan, Arfan dan Mohammad Ishak. 2005. Akuntansi Keperilakuan. Salemba Empat. Jakarta.

Indra, Bastian. 2005. Akuntansi Sektor Publik. Yogyakarta. BPFE.

Indriantoro, Nur dan Bambang Supomo. 2002. Metodologi Penelitian Bisnis untuk Akuntansi dan Manajemen. Edisi II. BPFE UGM. Yogyakarta.

Lubis, Arfan Ikhsan. 2010. Akuntansi Keperilakuan. Salemba Empat. Jakarta.

Mardiasmo. 2002. Akuntansi Sektor Publik. Andi Offiset. Yogyakarta.

Mahoney, T. A, Jerdee and S.J Carroll. 1963. Development of managerial performance. A Research Approach. Cincinnati. Ohio: South Western Publishing Co.

Mediaty. 2010. Pengaruh Partisipasi Penyusunan Anggaran, dan Gaya Kepemimpinan Terhadap Kinerja Aparatur Pemerintah Daerah. Majalah Ekonomi Tahun XX. Fakultas Ekonomi Universitas Hasanuddin. Makassar.

Nafarin, M. 2000. Penganggaran Perusahaan. Jakarta: Salemba Empat.

Nor, Wahyudin. 2007. Desentralisasi dan Gaya Kepemimpinan Sebagai Variabel Moderating Dalam Hubungan Antara Partisispasi Penyusunan Anggaran dan Kinerja Manajerial. Simposium Nasional Akuntansi $X$. Makasar.

Republik Indonesia. Undang-Undang No 32 Tahun 2004. Pemerintah Daerah. Citra Umbara. Bandung.
--------, Undang-Undang No 25 Tahun 2000. Sistem Perencanaan Pembangunan. Citra Umbara. Bandung.

Rudianto. 2009. Penganggaran : Konsep dan Teknik Penyusunan Anggaran. Erlangga. Jakarta.

Sugiyono. 2008. Metode Penelitian Bisnis. Bandung: CV Alfabeta. 
Sumadiyah dan Susanta. 2004. Job Relevant Information (JRI) dan Ketidakpastian Lingkungan dalam Hubungan Partisipasi Anggaran dan Kinerja Manajerial. Jurnal Ekonomi dan Bisnis Indonesia.

Sumarno, J. 2005. Pengaruh Komitmen Organisasi dan Gaya Kepemimpinan terhadap Hubungan antara Partisipasi Anggaran dan Kinerja Manajerial. Simposium Nasional Akuntansi VIII. Solo.
Supriyono, R.A. 2002. Akuntansi Manajemen I. Yogyakarta: BPFE 2006. Pengaruh Usia, Keinginan Sosial, Kecukupan Anggaran, Dan Partisipasi Penganggaran Terhadap Kinerja Manajer Di Indonesia.Jurnal Ekonomi Dan Bisnis Indonesia.

Thoha, Miftah. 2008. Perilaku Organisasi Konsep Dasar dan Aplikasinya. PT Raja Grafindo Persada. Jakarta. 